\title{
On the opposite trends of correlations between interaction energies and electrostatic potentials of chlorinated and methylated amine complexes stabilized by halogen bond
}

\author{
Wiktor Zierkiewicz $^{1}$ (D) Mariusz Michalczyk $^{1}$
}

Received: 1 June 2017 / Accepted: 14 September 2017 / Published online: 17 October 2017

(C) The Author(s) 2017. This article is an open access publication

\begin{abstract}
The halogen-bonded complexes between $\mathrm{F}_{3} \mathrm{CCl}$ and ammonia and their methylated and chlorinated derivatives are investigated by ab initio $\operatorname{CCSD}(\mathrm{T})$ and density functional BLYP-D3 methods. The interaction energies $(\Delta E)$ calculated at the $\operatorname{CCSD}(\mathrm{T}) / \mathrm{cc}-\mathrm{pVTZ}$ level range between -0.90 and $-2.57 \mathrm{kcal} \mathrm{mol}^{-1}$. In all the complexes studied, the AIM analysis has revealed the presence of only one attractive interaction (halogen bond). In the investigated chloramine complexes, an increasing number of the chlorine substituents leads to a decrease in the $\Delta E$, while the opposite effect is observed for the methylated amine complexes, namely the $\Delta E$ increases with the increasing number of the methyl groups on $\mathrm{N}$ atom. These energies are related to the most negative values on the electrostatic potential surfaces $\left(V_{s, \min }\right)$ of the ammonia derivatives. In the case of the chlorinated amine complexes, the positive correlation between the $\Delta E$ and $V_{s, \min }$ is observed. On the contrary, the negative correlation between these values is noted for the methylated amine complexes. The NBO results indicate that upon complexation with $\mathrm{F}_{3} \mathrm{CCl}$ the charge transfer (CT) from the lone pair on $\mathrm{N}[\mathrm{LP}(\mathrm{N})]$ to the $\sigma^{*}(\mathrm{CCl})$ orbital decreases with the number of the chlorine substituents, while it increases with the number of the methyl groups on the $\mathrm{N}$ atom. It is suggested that the increase in CT in the methylated amine complexes is associated with the weakening of negative hyperconjugation between $\mathrm{LP}(\mathrm{N})$ and trans antibonding $\sigma^{*}(\mathrm{CH})$ orbital(s). This effect is probably responsible for the negative
\end{abstract}

Wiktor Zierkiewicz

Wiktor.Zierkiewicz@pwr.edu.pl

Faculty of Chemistry, Wrocław University of Science and Technology, Wybrzeże Wyspiańskiego 27, 50-370 Wrocław, Poland correlation between $\Delta E$ and $V_{s, \min }$ in the methylated amine complexes.

Keywords Halogen-bonded complexes · Methylated amines $\cdot$ Chloramines $\cdot \operatorname{CCSD}(\mathrm{T}) \cdot \mathrm{DFT}$

\section{Introduction}

Different noncovalent interactions have been extensively studied in the recent years. One type of these interactions is halogen bond which plays a significant role in different fields such as crystal engineering [1-5], biomolecular systems [6-8], organic catalysis [9, 10] or optoelectronics $[11,12]$. Halogen bond is an attractive interaction between the positively charged fragment of the electrostatic surface $(\sigma$-hole) on the halogen atom $(\mathrm{Cl}, \mathrm{Br}, \mathrm{I})$ and the electronrich center (e.g., electron lone pair from nitrogen atom) $[13,14]$. This interaction is described in the literature as $\mathrm{R}-\mathrm{X}$... Y where $\mathrm{R}$ is a moiety covalently bonded with halogen atom $(\mathrm{X})$, and $\mathrm{Y}$ is a donor of electron density [15]. Halogen bond is explained by the theory of $\sigma$-hole proposed by Politzer and co-workers [16-18]. The strength of $\sigma$-hole can be determined by $V_{s, \max }$ [19] parameter, and it increases with an increase in polarizability and the size of the halogen atom. It also depends on electron-withdrawing properties of the group attached to the halogen [20]. The other factors affecting the quality of this interaction are: the most negative values of the electrostatic potential $\left(V_{s, \text { min }}\right)$ of the $\sigma$-hole acceptor, charge transfer from electron lone pair into the $\sigma^{*}(\mathrm{R}-\mathrm{X})$ antibonding orbital of the $\sigma$-hole donor [21-23] and dispersion forces [24, 25].

It was shown in the literature that the interaction energy $(\Delta E)$ in many complexes correlates with the most positive values of the electrostatic potential $\left(V_{s, \max }\right)$ of the electron 
acceptor ( $\sigma$-hole donor) [24, 26-28]. The bigger the value of $V_{s, \max }$, the bigger the absolute value of the interaction energy. Analogous correlation was found between the $\Delta E$ and the most negative values of the electrostatic potential $\left(V_{s, \min }\right)$ of the electron donors ( $\sigma$-hole acceptor) $[16,28,29]$.

Recently, Scheiner et al. reported that the trend of $V_{s, \min }$ was opposite to the pattern of binding energies for the chalcogen-bonded complexes of $\mathrm{SF}_{4}$ with alkylamines [30]. These authors investigated also complexes of $\mathrm{SF}_{4}$ with heteroaromatic amines, and they did not find any correlation between the values of the $\Delta E$ and $V_{s, \text { min. }}$. Finally, they concluded that " $V_{s, \min }$ is a poor indicator of binding strength" in the investigated complexes [30].

In our recent paper on the chalcogen-bonded complexes between ammonia derivatives and the $\mathrm{CS}_{2}$ molecule, we found that in the chloramine complexes, the interaction energies were ordered according to the $V_{s, \min }$ values of the electrostatic potential [31].

The main purpose of the present work is to discuss the nature of correlations between the values of the interaction energies and the $V_{s, \min }$ (as well as the other properties) of chlorinated and methylated amines in the halogen-bonded complexes with $\mathrm{F}_{3} \mathrm{CCl}$.

\section{Computational methods}

The optimized geometries and vibrational harmonic frequencies were calculated for the following bases: $\mathrm{NH}_{3}, \mathrm{NH}_{2} \mathrm{Cl}$, $\mathrm{NHCl}_{2}, \mathrm{NCl}_{3}, \mathrm{NH}_{2} \mathrm{CH}_{3}, \mathrm{NH}\left(\mathrm{CH}_{3}\right)_{2}, \mathrm{~N}\left(\mathrm{CH}_{3}\right)_{3}$ and for their complexes with $\mathrm{F}_{3} \mathrm{CCl}$. Vibrational frequency calculations confirmed that the optimized structures correspond to the minima on the potential energy surfaces. The BLYP-D3 method [32] with the Def2TZVPP basis set [33, 34] was used in the calculations. This functional was recommended by Hobza et al. for the complexes stabilized by noncovalent interactions [35].

The interaction energies between the molecules were determined at the BLYP-D3/Def2TZVPP and CCSD(T)/ cc-pVTZ levels of theory. The interaction energies were corrected for the basis set superposition error (BSSE) computed by the CP method [36].

The electron density of the investigated complexes was analyzed by the Atoms in Molecules (AIM) methodology [37] to characterize the intermolecular interactions. The presence of an AIM bond critical point (BCP) between the centers of the monomers in the complexes indicates the attractive interaction between them.

For the isolated molecules, the critical points on the electrostatic potential surface $\left(V_{s, \max }\right.$ and $\left.V_{s, \text { min }}\right)$ were computed using the WFA (Wavefunction Analysis) Program [38, 39]. A natural bond orbital (NBO) analysis has been performed for the isolated molecules as well as for their complexes
$[40,41]$. The calculations were carried out with the Gaussian 09 [42].

\section{Results and discussion}

\subsection{Structures of complexes and interaction energies}

The DFT optimized structures of $\mathrm{F}_{3} \mathrm{CCl}$ complexes with ammonia and its chlorinated and methylated derivatives are illustrated in Fig. 1. Selected intermolecular parameters are presented in Table 1. As follows from this table, in all the complexes the intermolecular $\mathrm{N} \cdots \mathrm{Cl}$ distances are smaller than the sum of the corresponding van der Waals radii (3.30 $\AA$ ). In chlorinated amine complexes, the $\mathrm{N} \cdots \mathrm{Cl}$ distance increases with the increasing number of the chlorine substituents. In the case of the methylated amine complexes, the corresponding distance decreases in the order of increasing number of the methyl groups. As follows from the results collected in Table 1, the $\mathrm{N} \cdots \mathrm{Cl}-\mathrm{C}$ angles are almost linear.

The interaction energies $(\Delta E)$ calculated at the BLYPD3/Def2TZVPP and CCSD(T)/cc-pVTZ levels of theory are collected in Table 2. In these complexes, the values of $\Delta E$ vary from -1.56 to $-4.81 \mathrm{kcal} \mathrm{mol}^{-1}$. These values are in the same order of magnitude as the values of the $\Delta E$ calculated for the chalcogen-bonded complexes of $\mathrm{CS}_{2}$ with chlorinated or methylated amines [31].

As follows from the data collected in Table 2, in chloramine complexes the absolute values of the $\Delta \mathrm{E}$ decrease in the order $\mathrm{NH}_{3}>\mathrm{NH}_{2} \mathrm{Cl}>\mathrm{NHCl}_{2}>\mathrm{NCl}_{3}$. The opposite trend is observed in the methylated amine complexes, where the values of the $|\Delta E|$ increase with the number of the methyl groups, in the following order $\mathrm{NH}_{3}<\mathrm{NH}_{2} \mathrm{CH}_{3}<\mathrm{NH}\left(\mathrm{CH}_{3}\right)_{2}<\mathrm{N}\left(\mathrm{CH}_{3}\right)_{3}$.

\subsection{Electrostatic potential}

Figure 2 illustrates the calculated molecular electrostatic potentials (MEPs) of isolated $\mathrm{F}_{3} \mathrm{CCl}$ and $\mathrm{NH}_{3}$. The values of the minima $\left(V_{s, \min }\right)$ on MEPs of ammonia and its derivatives as well as the most positive electrostatic potentials $\left(V_{s, \max }\right)$ of $\mathrm{F}_{3} \mathrm{CCl}(\sigma$-hole $)$ are collected in Table 3. It was demonstrated in our previous paper [31] that the substitution of one $\mathrm{H}$ atom of ammonia by the $\mathrm{Cl}$ atom results in a decrease in the value of $\left|V_{s, \min }\right|$ by about $10 \mathrm{kcal} \mathrm{mol}^{-1}$, while the substitution of one $\mathrm{H}$ atom by the $\mathrm{CH}_{3}$ group lowers the corresponding values by $2-3 \mathrm{kcal} \mathrm{mol}^{-1}$. According to the results presented in Table 3, the calculated value of $V_{s, \max }$ for $\mathrm{F}_{3} \mathrm{CCl}$ is $18.8 \mathrm{kcal} \mathrm{mol}^{-1}$.

It has been shown for several halogen- or chalcogenbonded complexes that the interaction energies correlate with the $V_{s, \max }$ on a $\sigma$-hole donor. The bigger the $V_{s, \max }$, the 
Fig. 1 Optimized structures of the complexes discussed in this work

\section{$\mathrm{F}_{3} \mathrm{CCl} \cdots \mathrm{NH}_{3}$}

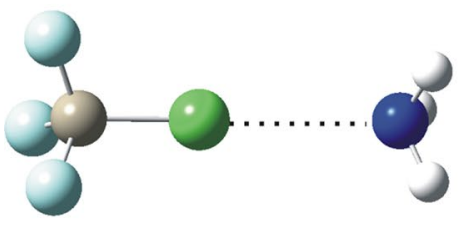

$\mathrm{F}_{3} \mathrm{CCl} \cdots \mathrm{NHCl}_{2}$

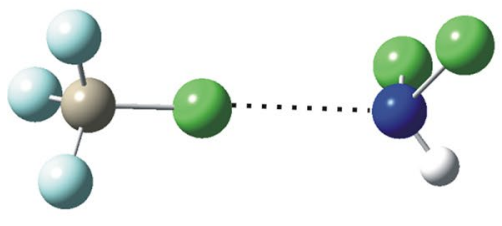

$\mathrm{F}_{3} \mathrm{CCl} \cdots \mathrm{NH}_{2} \mathrm{Cl}$

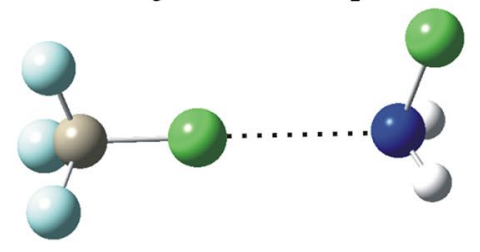

$\mathrm{F}_{3} \mathrm{CCl} \cdots \mathrm{NCl}_{3}$

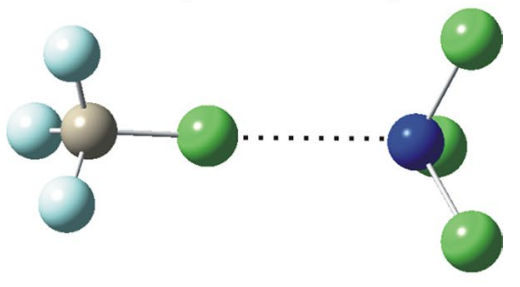

\section{$\mathrm{F}_{3} \mathrm{CCl} \cdots \mathrm{NH}_{2} \mathrm{CH}_{3}$}

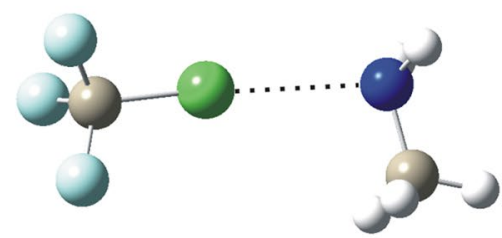

$\mathrm{F}_{3} \mathrm{CCl} \cdots \mathrm{NH}\left(\mathrm{CH}_{3}\right)_{2}$

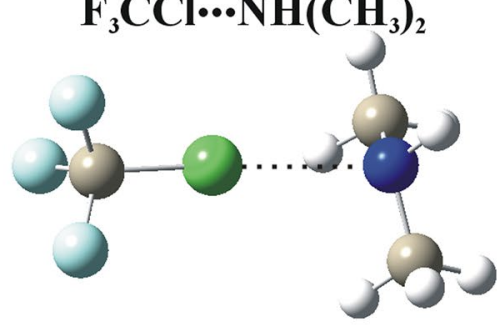

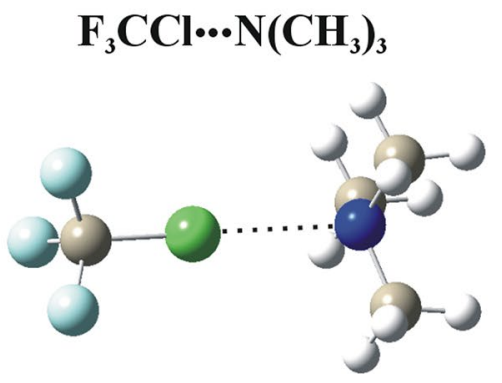

Table 1 Intermolecular parameters (distances in $\AA$, angles in degrees) in the $\mathrm{F}_{3} \mathrm{CCl}$ complexes with chlorinated and methylated amines calculated at the BLYP-D3/Def2TZVPP level of theory

\begin{tabular}{lll}
\hline Complex & $\mathrm{R}(\mathrm{N} \cdots \mathrm{Cl})$ & $\angle \mathrm{N} \cdots \mathrm{Cl}-\mathrm{C}$ \\
\hline $\mathrm{F}_{3} \mathrm{CCl} \cdots \mathrm{NH}_{3}$ & 2.985 & 179.6 \\
$\mathrm{~F}_{3} \mathrm{CCl} \cdots \mathrm{NH}_{2} \mathrm{Cl}$ & 3.066 & 179.7 \\
$\mathrm{~F}_{3} \mathrm{CCl} \cdots \mathrm{NHCl}_{2}$ & 3.119 & 178.8 \\
$\mathrm{~F}_{3} \mathrm{CCl} \cdots \mathrm{NCl}_{3}$ & 3.133 & 178.5 \\
$\mathrm{~F}_{3} \mathrm{CCl} \cdots \mathrm{NH}_{2} \mathrm{CH}_{3}$ & 2.912 & 175.2 \\
$\mathrm{~F}_{3} \mathrm{CCl} \cdots \mathrm{NH}\left(\mathrm{CH}_{3}\right)_{2}$ & 2.858 & 174.6 \\
$\mathrm{~F}_{3} \mathrm{CCl} \cdots \mathrm{N}\left(\mathrm{CH}_{3}\right)_{3}$ & 2.819 & 179.4 \\
\hline
\end{tabular}

Table 2 Interaction energies ( $\left.\Delta E, \mathrm{kcal} \mathrm{mol}^{-1}\right)$ of the halogen-bonded complexes calculated at the BLYP-D3/Def2TZVPP (I) and CCSD(T)/ cc-pVTZ (II) levels of theory

\begin{tabular}{lll}
\hline Complex & $\Delta E(\mathrm{I})$ & $\Delta E(\mathrm{II})$ \\
\hline $\mathrm{F}_{3} \mathrm{CCl} \cdots \mathrm{NH}_{3}$ & $-3.36(-3.07)^{\mathrm{a}}$ & $-2.80(-2.16)$ \\
$\mathrm{F}_{3} \mathrm{CCl} \cdots \mathrm{NH}_{2} \mathrm{Cl}$ & $-2.46(-2.27)$ & $-2.12(-1.52)$ \\
$\mathrm{F}_{3} \mathrm{CCl} \cdots \mathrm{NHCl}_{2}$ & $-1.98(-1.83)$ & $-1.73(-1.06)$ \\
$\mathrm{F}_{3} \mathrm{CCl} \cdots \mathrm{NCl}_{3}$ & $-1.72(-1.56)$ & $-1.58(-0.90)$ \\
$\mathrm{F}_{3} \mathrm{CCl} \cdots \mathrm{NH}_{2} \mathrm{CH}_{3}$ & $-4.18(-3.81)$ & $-3.27(-2.34)$ \\
$\mathrm{F}_{3} \mathrm{CCl} \cdots \mathrm{NH}\left(\mathrm{CH}_{3}\right)_{2}$ & $-4.82(-4.39)$ & $-3.71(-2.57)$ \\
$\mathrm{F}_{3} \mathrm{CCl} \cdots \mathrm{N}\left(\mathrm{CH}_{3}\right)_{3}$ & $-5.30(-4.81)$ & $-3.90(-2.54)$ \\
\hline
\end{tabular}

${ }^{\mathrm{a}}$ Interaction energies corrected for BSSE are given in parentheses 


\section{$\mathrm{CF}_{3} \mathrm{Cl}$}

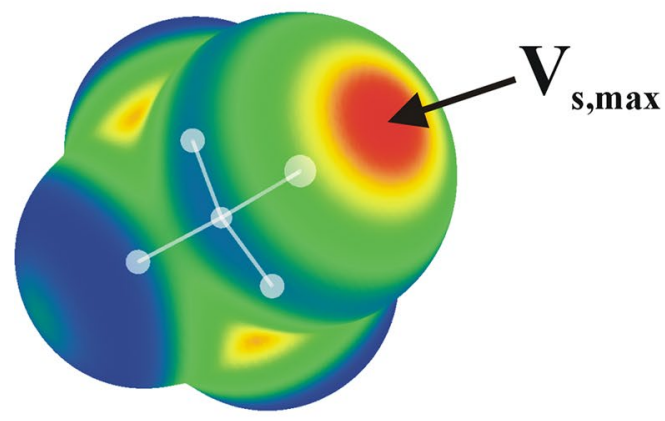

$\mathrm{NH}_{3}$

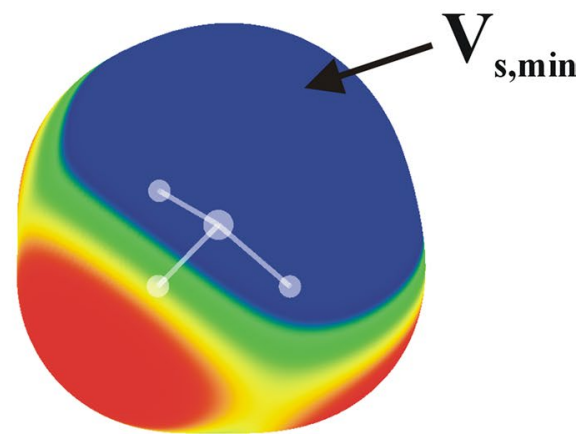

Fig. 2 Molecular electrostatic potentials (MEPs) of isolated $\mathrm{F}_{3} \mathrm{CCl}$ and $\mathrm{NH}_{3}$ molecules on the 0.001 a.u. contour of the electron density computed at the BLYP-D3/Def2TZVPP level. Color ranges, in

Table 3 Molecular electrostatic potentials extrema (in $\mathrm{kcal} \mathrm{mol}^{-1}$ ) on ammonia nitrogen atom $\left(V_{s, \min }\right)$ of isolated amines and on $\mathrm{Cl}$ atom of $\mathrm{CF}_{3} \mathrm{Cl}\left(V_{s, \text { max }}\right)$ on the 0.001 a.u. contour of the electrostatic density calculated at the BLYP-D3/Def2TZVPP level of theory

\begin{tabular}{ll}
\hline Isolated molecule & $V_{s, \text { min }}^{\mathrm{a}}$ \\
\hline $\mathrm{NH}_{3}$ & -37.8 \\
$\mathrm{NH}_{2} \mathrm{Cl}$ & -27.5 \\
$\mathrm{NHCl}_{2}$ & -17.9 \\
$\mathrm{NCl}_{3}$ & -8.3 \\
$\mathrm{NH}_{2} \mathrm{CH}_{3}$ & -35.9 \\
$\mathrm{NH}_{\left(\mathrm{CH}_{3}\right)_{2}}$ & -32.5 \\
$\mathrm{~N}\left(\mathrm{CH}_{3}\right)_{3}$ & -29.0 \\
& $V_{s, \max }^{\mathrm{b}}$ \\
$\mathrm{CF}_{3} \mathrm{Cl}$ & +18.8 \\
\hline
\end{tabular}

${ }^{\text {a }}$ The values of the $V_{s, \min }$ were reported in our earlier paper Ref. [30]

${ }^{\mathrm{b}}$ This work

$\mathrm{kcal} \mathrm{mol}{ }^{-1}$, are: red greater than 15 , yellow between 8 and 15 , green between 0 and 8 , blue less than 0 (negative)

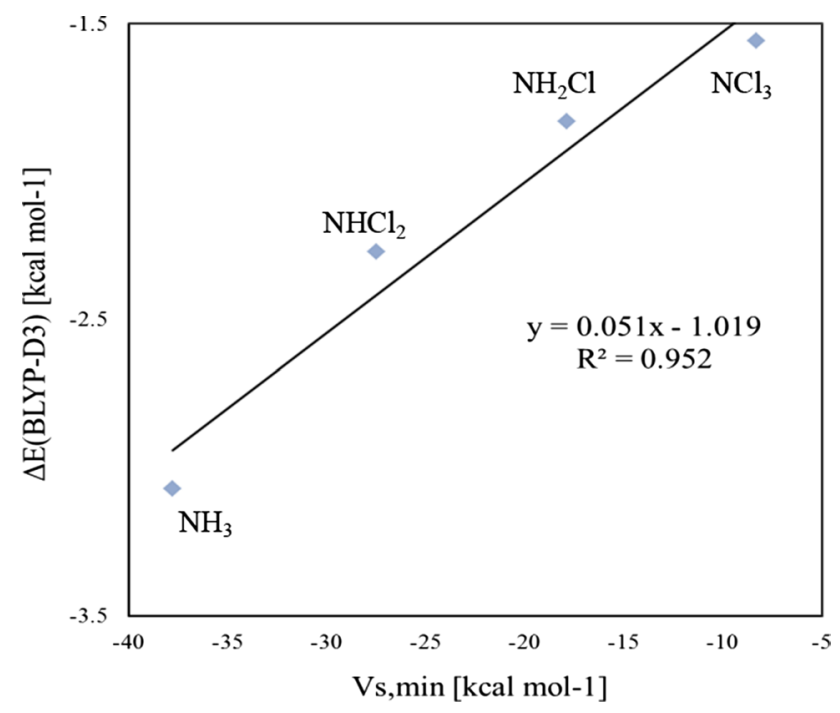

Fig. $3 \Delta E\left(\mathrm{kcal} \mathrm{mol}^{-1}\right)$ as a function of $V_{s, \min }\left(\mathrm{kcal} \mathrm{mol}^{-1}\right)$ for chloramine complexes with $\mathrm{F}_{3} \mathrm{CCl}$ studied in this work

bigger the values of the $|\Delta E|[24,26-28]$. Similar effect was obtained for the complexes studied in this work.

It was reported that the $\Delta E$ can be correlated with the most negative values of the electrostatic potential $\left(V_{s, \min }\right)$ of an electron donor ( $\sigma$-hole acceptor). The bigger the absolute value of $V_{s, \min }$, the bigger the absolute value of the interaction energy [16, 28, 29]. Politzer et al. [16] performed calculations for $\mathrm{SiF}_{4}$ and $\mathrm{SiCl}_{4}$ complexes with two different Lewis bases $\mathrm{NH}_{3}$ and $\mathrm{HCN}$. They found that the ammonia complexes are distinctly more stable (more negative $\Delta E$ ) than those of HCN. They explained this fact as a consequence of considerably more negative potential of $\mathrm{NH}_{3}\left(V_{s, \text { min }}=-46.3 \mathrm{kcal} /\right.$ mole $)$ than that calculated for $\operatorname{HCN}\left(V_{s, \min }=-32.9 \mathrm{kcal} / \mathrm{mole}\right)$. In our earlier work [29] on the halogen-bonded complexes between carbonyl bases and molecular chlorine, it was found that the $\Delta E$ correlates with the $V_{s, \min }$ with a correlation coefficient $\left(R^{2}\right)$ of 0.916 .

As illustrated in Fig. 3, the positive correlation between the $\Delta E$ and the $V_{s, \min }$ of ammonia and its chlorinated derivatives is consistent with this observation. This correlation is linear and can be written as:

$\Delta E=0.051 V_{s, \min }-1.019 \quad\left(R^{2}=0.952\right)$

In the case of the $\mathrm{CS}_{2}$ complexes with chloramines, a similar correlation was found [31].

However, in the case of the methylated amine complexes studied in this work the opposite trend (negative correlation) has been found. As shown in Fig. 4, the values 


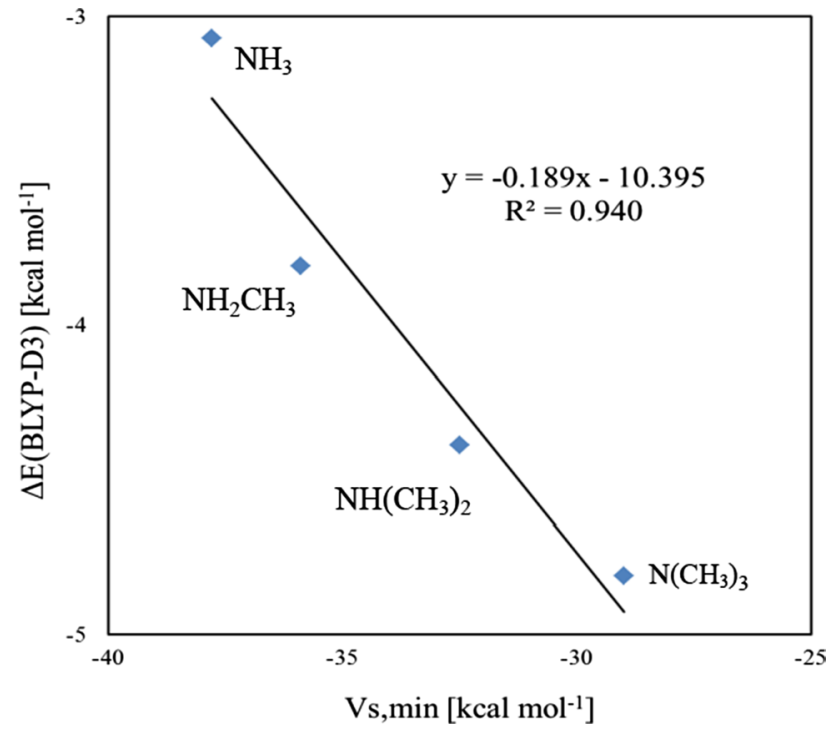

Fig. $4 \Delta E\left(\mathrm{kcal} \mathrm{mol}^{-1}\right)$ as a function of $V_{s, \min }\left(\mathrm{kcal} \mathrm{mol}^{-1}\right)$ for methylated amine complexes with $\mathrm{F}_{3} \mathrm{CCl}$ studied in this work

Table 4 Bond critical points (BCP) properties: electron density $\rho$, Laplacian of electron density $\nabla^{2} \rho$ (both in atomic units) and total electron energy $\left(\mathrm{H}, \mathrm{kcal} \mathrm{mol}^{-1}\right)$. Calculations were performed at the BLYP-D3/Def2TZVPP level

\begin{tabular}{lllll}
\hline System & Interaction & $\rho$ & $\nabla^{2} \rho$ & $\mathrm{H}$ \\
\hline $\mathrm{F}_{3} \mathrm{CCl} \cdots \mathrm{NH}_{3}$ & $\mathrm{Cl} \cdots \mathrm{N}$ & 0.014 & 0.045 & 1.00 \\
$\mathrm{~F}_{3} \mathrm{CCl} \cdots \mathrm{NH}_{2} \mathrm{Cl}$ & $\mathrm{Cl} \cdots \mathrm{N}$ & 0.011 & 0.038 & 1.07 \\
$\mathrm{~F}_{3} \mathrm{CCl} \cdots \mathrm{NHCl}_{2}$ & $\mathrm{Cl} \cdots \mathrm{N}$ & 0.009 & 0.034 & 1.07 \\
$\mathrm{~F}_{3} \mathrm{CCl} \cdots \mathrm{NCl}_{3}$ & $\mathrm{Cl} \cdots \mathrm{N}$ & 0.009 & 0.033 & 1.06 \\
$\mathrm{~F}_{3} \mathrm{CCl} \cdots \mathrm{NH}_{2} \mathrm{CH}_{3}$ & $\mathrm{Cl} \cdots \mathrm{N}$ & 0.017 & 0.051 & 0.94 \\
$\mathrm{~F}_{3} \mathrm{CCl} \cdots \mathrm{NH}_{3}\left(\mathrm{CH}_{3}\right)_{2}$ & $\mathrm{Cl} \cdots \mathrm{N}$ & 0.019 & 0.056 & 0.87 \\
$\mathrm{~F}_{3} \mathrm{CCl} \cdots \mathrm{N}\left(\mathrm{CH}_{3}\right)_{3}$ & $\mathrm{Cl} \cdots \mathrm{N}$ & 0.020 & 0.059 & 0.76 \\
\hline
\end{tabular}

of the interaction energies $\Delta E$ correlate inversely with $V_{s, \min }$. This correlation is also linear and can be written as:

$\Delta E=-0.189 V_{s, \min }-10.395 \quad\left(R^{2}=0.940\right)$

The question arises what is the origin of this peculiar characteristic of methylated amine complexes with $\mathrm{F}_{3} \mathrm{CCl}$ ?

\subsection{AIM analysis}

The presence of the bond critical points (BCPs) between the atoms indicates the attractive bonding interactions. The results of the Atoms in Molecules (AIM) analysis of the selected BCPs are collected in Table 4. As follows from this table, in chlorinated amine complexes the values of electron density $(\rho)$ and Laplacian of electron density $\left(\Delta^{2} \rho\right)$ slightly decrease with the number of chlorine atoms, while the opposite trend is observed with respect to the methylated amine complexes. The AIM analysis has revealed that all the complexes are stabilized by only one interaction, namely the $\mathrm{Cl} \cdots \mathrm{N}$ halogen bond. Figure 5 demonstrates the existence of one BCP between the interacting subunits, in the $\mathrm{F}_{3} \mathrm{CCl} \cdots \mathrm{NCl}_{3}$ and $\mathrm{F}_{3} \mathrm{CCl} \cdots \mathrm{N}\left(\mathrm{CH}_{3}\right)_{3}$ complexes.

According to the Popelier's criteria for the hydrogen bonds, the electron density at the BCP ranges from 0.002 to $0.035 \mathrm{au}$, and the Laplacian of the electron density ranges from 0.024 to 0.139 au $[43,44]$. All of the complexes investigated in this work fulfill these criteria.

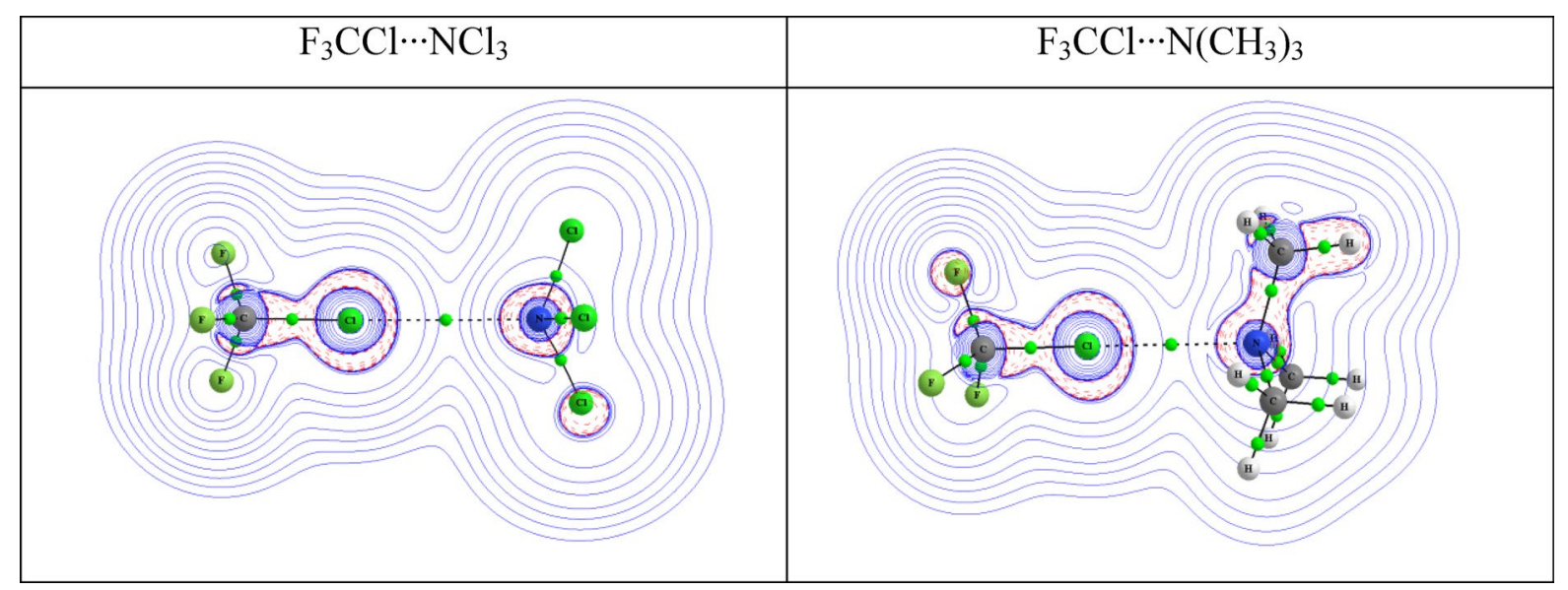

Fig. 5 Contour line diagram of the Laplacian of the electron density of the $\mathrm{F}_{3} \mathrm{CCl} \cdots \mathrm{NCl}_{3}$ and $\mathrm{F}_{3} \mathrm{CCl} \cdots \mathrm{N}\left(\mathrm{CH}_{3}\right)_{3}$ complexes (in the plane passing through the $\mathrm{N}, \mathrm{Cl}$ and $\mathrm{C}$ atoms). The solid (blue) lines represent the positive values of the Laplacian, while the dashed (red) lines represent the negative values. Small green points represent the bond critical points (BCP). Calculations were performed at the BLYP-D3/ Def2TZVPP level 


\subsection{NBO analysis}

\subsubsection{Isolated amines}

In our previous paper on the chalcogen-bonded complexes of $\mathrm{CS}_{2}$, the variations of charges on the $\mathrm{N}$ atom in isolated chlorinated and methylated amines were discussed [31]. It was shown that the substitution of the $\mathrm{H}$ atom(s) in ammonia by the chlorine atom(s) or the methyl group(s) decreases the absolute values of the negative charge on the nitrogen atom. Therefore, in isolated amines both the $\mathrm{Cl}$ and $\mathrm{CH}_{3}$ substituents act as the electron-withdrawing groups.

The natural charges calculated on the nitrogen atom $q(N)$ in isolated amines were reported in the paper [31]. Comparison of these data and the values of the minima on MEPs of ammonia and its derivatives clearly shows that the values of the $V_{s, \min }$ and $q(N)$ are linearly correlated with according to the following equations:

$V_{s, \min }=43.634 q(N)+6.447 \quad\left(R^{2}=0.977\right)$

for chlorinated amines

$V_{s, \min }=13.606 q(N)-24.180 \quad\left(R^{2}=0.973\right)$

for methylated amines

A decrease in the absolute values of the negative charge on the nitrogen atom in chloramines is expected from a larger electronegativity of $\mathrm{Cl}$, in comparison with $\mathrm{N}$ atom. However, for the methyl substituents the explanation is different.

In this case, a decrease in the $|q(N)|$ is caused by the negative hyperconjugation (a lone pair effect), which is an intramolecular stabilizing interaction between lone pair orbital on $\mathrm{N}$ and adjacent antibonding $\sigma^{*}(\mathrm{CH})$ orbital(s) [31, 45-47]. When a carbon atom of the methyl group is attached to an amine nitrogen and a $\mathrm{C}-\mathrm{H}$ bond is anticoplanar to the nitrogen lone pair $\operatorname{LP}(\mathrm{N})$, a transfer of the electron density from the LP(N) into the sigma antibonding $\sigma^{*}(\mathrm{C}-\mathrm{H})_{\text {trans }}$ orbital occurs. This leads to a weakening and elongation of the anti-coplanar $\mathrm{C}-\mathrm{H}$ bond, in comparison with the other two $\mathrm{C}-\mathrm{H}$ bonds of the methyl group. Moreover, the $\mathrm{C}-\mathrm{H}$ stretching frequency of this particular bond is redshifted, by about $100-150 \mathrm{~cm}^{-1}$. This phenomenon is observed in IR spectroscopy and is also known as the Bohlmann effect [48]. A classic negative hyperconjugation is illustrated in Fig. 6.

We have examined the occupancy of the $\mathrm{LP}(\mathrm{N})$ and the characteristic features of $\mathrm{C}-\mathrm{H}$ bonds: the occupancy of $\sigma^{*}(\mathrm{C}-\mathrm{H})$ orbitals, $\mathrm{C}-\mathrm{H}$ distances, $\mathrm{C}-\mathrm{H}$ stretching frequencies and second-order interaction energies between selected orbitals in the isolated methylated amines and their complexes with $\mathrm{F}_{3} \mathrm{CCl}$. Table 5 collects the results obtained for the isolated methylated amines.

\section{isolated $\mathrm{NH}_{2} \mathrm{CH}_{3}$}

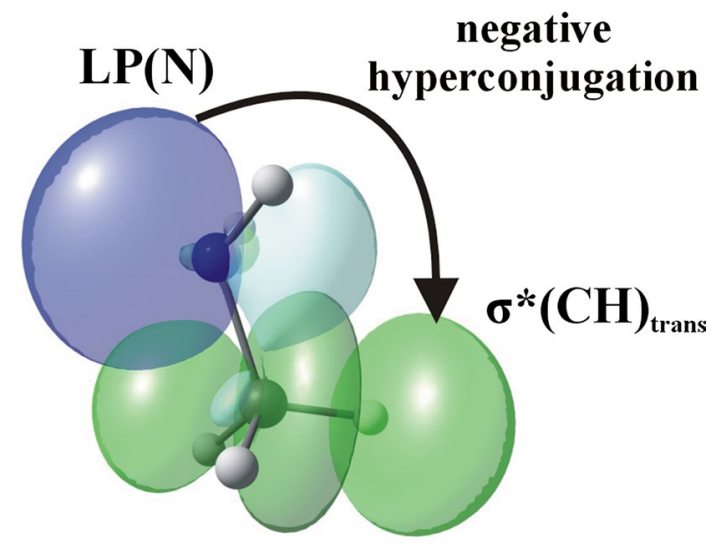

Fig. 6 Negative hyperconjugation between $\mathrm{LP}(\mathrm{N})$ and $\sigma^{*}(\mathrm{C}-\mathrm{H})_{\text {trans }}$ orbitals in isolated methylamine

Table $5 \mathrm{LP}(\mathrm{N})$ and $\sigma^{*}(\mathrm{C}-\mathrm{H})$ occupancies (in me), $\mathrm{C}-\mathrm{H}$ bond lengths $\left(R\right.$ in $\AA$ ), $\mathrm{C}-\mathrm{H}$ stretching frequencies $\left(\nu\right.$ in $\left.\mathrm{cm}^{-1}\right)$ and the sum of $E^{2}$ interaction energies between selected orbitals (in $\mathrm{kcal} \mathrm{mol}^{-1}$ ) in isolated methylated amines. The calculations were performed at the BLYP-D3/Def2TZVPP level of theory

\begin{tabular}{llll}
\hline & $\mathrm{NH}_{2} \mathrm{CH}_{3}$ & $\mathrm{NH}\left(\mathrm{CH}_{3}\right)_{2}$ & $\mathrm{~N}\left(\mathrm{CH}_{3}\right)_{3}$ \\
\hline $\mathrm{LP}(\mathrm{N})^{\mathrm{a}}$ & 1957 & 1903 & 1848 \\
$\Sigma \sigma^{*}(\mathrm{C}-\mathrm{H})_{\text {trans }}$ & $29^{\mathrm{b}}$ & $70^{\mathrm{c}}$ & $114^{\mathrm{c}}$ \\
$\Sigma \sigma^{*}(\mathrm{C}-\mathrm{H})_{\text {other }}$ & $24^{\mathrm{c}}$ & $48^{\mathrm{c}}$ & $60^{\mathrm{c}}$ \\
$R(\mathrm{C}-\mathrm{H})_{\text {trans }}$ & 1.106 & $1.110^{\mathrm{d}}$ & $1.112^{\mathrm{d}}$ \\
$R(\mathrm{C}-\mathrm{H})_{\text {other }}$ & $1.097^{\mathrm{d}}$ & $1.098^{\mathrm{d}}$ & $1.097^{\mathrm{d}}$ \\
$\nu(\mathrm{C}-\mathrm{H})_{\text {trans }}$ & 2878 & $2841^{\mathrm{d}}$ & $2826^{\mathrm{d}}$ \\
$\nu(\mathrm{C}-\mathrm{H})_{\text {other }}$ & 3014 & $3015^{\mathrm{d}}$ & $3019^{\mathrm{d}}$ \\
$\Sigma E^{2} \mathrm{LP}(\mathrm{N}) \rightarrow \sigma^{*}(\mathrm{CH})_{\text {trans }}$ & $6.82^{\mathrm{b}}$ & $14.40^{\mathrm{c}}$ & $21.63^{\mathrm{c}}$ \\
$\Sigma E^{2} \mathrm{LP}(\mathrm{N}) \rightarrow \sigma^{*}(\mathrm{CH})_{\text {other }}$ & $2.22^{\mathrm{c}}$ & $4.77^{\mathrm{c}}$ & $6.64^{\mathrm{c}}$ \\
\hline
\end{tabular}

${ }^{\mathrm{a}} \mathrm{LP}(\mathrm{N})$ is the lone pair orbital on the nitrogen atom of amine; trans is the antibonding sigma orbital of the $\mathrm{C}-\mathrm{H}$ bond involved in negative hyperconjugation

${ }^{b}$ Data cited from Ref. [30]

${ }^{\mathrm{c}}$ The sum of the corresponding values

${ }^{\mathrm{d}}$ The average value

In the isolated ammonia molecule, the occupancy of the LP(N) orbital is 1997 me. As follows from Table 5, this occupancy decreases upon substitution by about -50 me per each of the methyl groups. These changes are accompanied by an increase in the occupancy on the $\Sigma \sigma^{*}(\mathrm{C}-\mathrm{H})_{\text {trans }}$ orbital. An increase in the occupancy on the other $\Sigma \sigma^{*}(\mathrm{C}-\mathrm{H})_{\text {other }}$ orbitals is much smaller. One should remember that in the case of $\Sigma \sigma^{*}(\mathrm{C}-\mathrm{H})_{\text {other }}$ the number of the components in a sum is twice bigger than that of the $\Sigma \sigma^{*}(\mathrm{C}-\mathrm{H})_{\text {trans }}$ 
orbitals. As follows from Table 5, the total occupancy of $\Sigma \sigma^{*}(\mathrm{C}-\mathrm{H})_{\text {trans }}$ and $\Sigma \sigma^{*}(\mathrm{C}-\mathrm{H})_{\text {other }}$ is comparable to the decrease in the occupancy on the $\mathrm{LP}(\mathrm{N})$.

The anti-coplanar (trans) $\mathrm{C}-\mathrm{H}$ bond is longer than the other two $\mathrm{C}-\mathrm{H}$ bonds of the methyl group, by $0.009,0.012$ and $0.015 \AA$, in $\mathrm{NH}_{2} \mathrm{CH}_{3}, \mathrm{NH}\left(\mathrm{CH}_{3}\right)_{2}$ and $\mathrm{N}\left(\mathrm{CH}_{3}\right)_{3}$, respectively. The corresponding $\mathrm{C}-\mathrm{H}$ stretching frequencies are redshifted by 101,126 and $154 \mathrm{~cm}^{-1}$, respectively.

In the last two rows of Table 5, the second-order interaction energies between $\mathrm{LP}(\mathrm{N})$ and antibonding $\sigma^{*}(\mathrm{CH})$ orbitals are listed. The sum of $\Sigma E^{2}\left(\mathrm{LP}(\mathrm{N}) \rightarrow \sigma^{*}(\mathrm{CH})_{\text {trans }}\right)$ values increases in the order $\mathrm{NH}_{2} \mathrm{CH}_{3}<\mathrm{NH}\left(\mathrm{CH}_{3}\right)_{2}<\mathrm{N}\left(\mathrm{CH}_{3}\right)_{3}$. It should be noted that these values are significantly larger than those of $\Sigma \mathrm{E}^{2}\left(\mathrm{LP}(\mathrm{N}) \rightarrow \sigma^{*}(\mathrm{CH})_{\text {other }}\right)$.

All of these results indicate that the negative hyperconjugation increases in the order methylamine $<$ dimethylamine $<$ trimethylamine. This effect can also explain a decrease in the absolute values of $V_{s, \min }$ in the order: methylamine $>$ dimethylamine $>$ trimethylamine.

\subsubsection{Amine complexes with $\mathrm{F}_{3} \mathrm{CCl}$}

It was reported for the methylated amine complexes with $\mathrm{H}^{+}$ that the more alkyl groups were connected with $N$, the more stable was the cation [49]. Experimental gas-phase basicities, defined as $\Delta G$, for the protonation reaction of $\mathrm{NH}_{3}$, $\mathrm{NH}_{2} \mathrm{CH}_{3}, \mathrm{NH}\left(\mathrm{CH}_{3}\right)_{2}$ and $\mathrm{N}\left(\mathrm{CH}_{3}\right)_{3}$ are $-196,-206,-213$ and $-217 \mathrm{kcal} \mathrm{mol}^{-1}$, respectively [49]. It is worth mentioning that the lone pair effect (negative hyperconjugation) was studied in the hydrogen-bonded complexes between phenol derivatives and trimethylated amines [50].

In this work, we have shown that the absolute values of the interaction energy $(\Delta E)$ of the $\mathrm{F}_{3} \mathrm{CCl}$ complexes with methylated amines increase in the order methylamine $<$ dimethylamine $<$ trimethylamine (see Table 2 ), and these results are consistent with those reported in the literature [49].

In our previous studies on the chalcogen-bonded complexes between $\mathrm{CS}_{2}$ and ammonia derivatives, it was demonstrated that these complexes were stabilized by a charge transfer $(\mathrm{CT})$ from the $\mathrm{LP}(\mathrm{N})$ to the $\sigma^{*}(\mathrm{CS})$ orbital [31]. A similar effect has been found for the complexes studied in the present work. The NBO analysis has revealed that upon complexation the $\mathrm{CT}$ from the $\mathrm{LP}(\mathrm{N})$ of the ammonia derivatives to the $\sigma^{*}(\mathrm{CCl})$ orbital occurs. Table 6 lists the values of second-order interaction energies $\left(E^{2}\right)$ between $\mathrm{LP}(\mathrm{N})$ and antibonding $\sigma^{*}(\mathrm{C}-\mathrm{Cl})$ orbital and the values of the $\mathrm{CT}$ taking place from the amines to the $\mathrm{F}_{3} \mathrm{CCl}$ molecule.

As follows from Table 6, for the chlorinated amine complexes, both the $E^{2}$ and CT values decrease with the number of the chlorine atoms. The opposite trend is observed in the case of the methylated amine complexes, where the values of $E^{2}$ and CT increase with the number of the
Table 6 Interaction energy $\left(E^{2}\right)$ between lone electron pair on nitrogen atom and antibonding $\sigma^{*}(\mathrm{C}-\mathrm{Cl})$ orbital $\left(\mathrm{kcal} \mathrm{mol}^{-1}\right)$ and charge transfer $(\mathrm{CT}$, in me) in the studied complexes

\begin{tabular}{llr}
\hline Complex & $E^{2} \mathrm{LP}(\mathrm{N}) \rightarrow \sigma^{*}(\mathrm{C}-\mathrm{Cl})$ & $\mathrm{CT}$ \\
\hline $\mathrm{F}_{3} \mathrm{CCl} \cdots \mathrm{NH}_{3}$ & 2.88 & 27 \\
$\mathrm{~F}_{3} \mathrm{CCl} \cdots \mathrm{NH}_{2} \mathrm{Cl}$ & 1.57 & 14 \\
$\mathrm{~F}_{3} \mathrm{CCl} \cdots \mathrm{NHCl}_{2}$ & 0.87 & 6 \\
$\mathrm{~F}_{3} \mathrm{CCl} \cdots \mathrm{NCl}_{3}$ & 0.55 & 1 \\
$\mathrm{~F}_{3} \mathrm{CCl} \cdots \mathrm{NH}_{2} \mathrm{CH}_{3}$ & 3.40 & 37 \\
$\mathrm{~F}_{3} \mathrm{CCl} \cdots \mathrm{NH}_{3}\left(\mathrm{CH}_{3}\right)_{2}$ & 3.78 & 46 \\
$\mathrm{~F}_{3} \mathrm{CCl} \cdots \mathrm{N}\left(\mathrm{CH}_{3}\right)_{3}$ & 3.85 & 51 \\
\hline
\end{tabular}

methyl groups. It should be stressed that the values of $E^{2}$ and CT perfectly correlate with the $\Delta E$. The correlation coefficients $\left(R^{2}\right)$ between the $\Delta E$ and $\mathrm{CT}$ are equal to 0.999 and 0.998 for chloramine and methylated amines complexes, respectively.

$$
\begin{gathered}
\Delta E=-0.058 C T-1.485 \quad\left(R^{2}=0.999\right) \\
\text { for chlorinated amine complexes }
\end{gathered}
$$

$$
\begin{gathered}
\Delta E=-0.071 C T-1.148 \quad\left(R^{2}=0.998\right) \\
\text { for methylated amine complexes }
\end{gathered}
$$

In the case of the chloramine complexes, the situation is clear. The smaller are the values of $|q(N)|$ (or $\left|V_{s, \text { min }}\right|$ ) in isolated chloramines, the smaller are the values of $E^{2}$, $\mathrm{CT}$ and $|\Delta E|$ in complexes with $\mathrm{F}_{3} \mathrm{CCl}$. In the methylated amine complexes, the relationship is reverse; the smaller are the values of $|q(N)|$ (or $\left|V_{s, \text { min }}\right|$ ) in isolated methylated amines, the larger are $E^{2}, \mathrm{CT}$ and $|\Delta E|$ in their complexes with $\mathrm{F}_{3} \mathrm{CCl}$.

Again the question arises: How can we explain these correlations in the methylated amine complexes? To answer this question, we have investigated the changes in negative hyperconjugation in these molecules caused by complexation. In Table 7, the calculated data for methylated amine complexes are collected. The changes caused by complexation are given in parentheses.

As follows from the results collected in this table, in all complexes the occupancy of the LP(N) orbital decreases upon complexation. Surprisingly, the calculated values of these changes are similar in all methylated amine complexes and range between -35 and -33 me. As follows from the data given in Table 6, the values of CT are larger than the changes of the occupancy of the LP(N) orbitals by 4,11 and 18 me for methylamine, dimethylamine and trimethylamine complexes, respectively. As listed in Table 7, upon complexation with $\mathrm{F}_{3} \mathrm{CCl}$ the occupancy of the $\Sigma \sigma^{*}(\mathrm{C}-\mathrm{H})_{\text {trans }}$ orbital decreases with the number of the substituting methyl groups by $-3,-8$ and -15 me, respectively. 
Table $7 \mathrm{LP}(\mathrm{N})$ and $\sigma^{*}(\mathrm{C}-\mathrm{H})$ occupancies (in me), $\mathrm{C}-\mathrm{H}$ bond length ( $\mathrm{R}$ in $\AA$ ) , $\mathrm{C}-\mathrm{H}$ stretching frequencies $\left(\nu\right.$ in $\left.\mathrm{cm}^{-1}\right)$ and $E^{2}$ interaction energies between selected orbitals (in $\mathrm{kcal} \mathrm{mol}^{-1}$ ) in the investigated complexes

\begin{tabular}{llll}
\hline & $\mathrm{F}_{3} \mathrm{CCl} \cdots \mathrm{Y}$ complexes $^{\mathrm{a}}$ & & \\
\hline & $\mathrm{Y}=\mathrm{NH}_{2} \mathrm{CH}_{3}$ & $\mathrm{Y}=\mathrm{NH}\left(\mathrm{CH}_{3}\right)_{2}$ & $\mathrm{Y}=\mathrm{N}_{\left(\mathrm{CH}_{3}\right)_{3}}$ \\
$\mathrm{LP}(\mathrm{N})^{\mathrm{b}}$ & $1924(-33)$ & $1868(-35)$ & $1815(-33)$ \\
$\Sigma \sigma^{*}(\mathrm{C}-\mathrm{H})_{\text {trans }}$ & $26(-3)$ & $62(-8)^{\mathrm{c}}$ & $99(-15)^{\mathrm{c}}$ \\
$\Sigma \sigma^{*}(\mathrm{C}-\mathrm{H})_{\text {other }}$ & $24(0)^{\mathrm{c}}$ & $46(-2)^{\mathrm{c}}$ & $60(0)^{\mathrm{c}}$ \\
$\mathrm{R}(\mathrm{C}-\mathrm{H})_{\text {trans }}$ & $1.104(-0.002)$ & $1.107(-0.003)^{\mathrm{d}}$ & $1.110(-0.003)^{\mathrm{d}}$ \\
$\mathrm{R}(\mathrm{C}-\mathrm{H})_{\text {other }}$ & $1.096(-0.001)^{\mathrm{d}}$ & $1.097(-0.001)^{\mathrm{d}}$ & $1.096(-0.001)^{\mathrm{d}}$ \\
$\nu(\mathrm{C}-\mathrm{H})_{\text {trans }}$ & $2901(+23)$ & $2867(+26)^{\mathrm{d}}$ & $2852(+26)^{\mathrm{d}}$ \\
$\nu(\mathrm{C}-\mathrm{H})_{\text {other }}$ & $3026(+12)$ & $3025(+10)^{\mathrm{d}}$ & $3028(+9)^{\mathrm{d}}$ \\
$\Sigma E^{2} \mathrm{LP}(\mathrm{N}) \rightarrow \sigma^{*}(\mathrm{CH})_{\text {trans }}$ & $6.25(-0.57)$ & $13.27(-1.13)^{\mathrm{c}}$ & $19.96(-1.67)^{\mathrm{c}}$ \\
$\Sigma E^{2} \mathrm{LP}(\mathrm{N}) \rightarrow \sigma^{*}(\mathrm{CH})_{\text {other }}$ & $2.21(-0.01)^{\mathrm{c}}$ & $4.74(-0.03)^{\mathrm{c}}$ & $6.54(-0.10)^{\mathrm{c}}$ \\
\hline
\end{tabular}

The calculations were performed at the BLYP-D3/Def2TZVPP level of theory

${ }^{\mathrm{a}}$ In parentheses are shown the changes caused by complexation with $\mathrm{F}_{3} \mathrm{CCl}$

${ }^{b} \mathrm{LP}(\mathrm{N})$ the lone pair orbital on the nitrogen atom of amine; trans is the $\mathrm{C}-\mathrm{H}$ bond orbital involved in the negative hyperconjugation

${ }^{\mathrm{c}}$ The sum of the corresponding values

${ }^{\mathrm{d}}$ The average value
Thus, it seems that a decrease in electron density (ED) on the $\mathrm{N}$ atom due to a charge transfer from $\mathrm{LP}(\mathrm{N})$ to $\sigma^{*}(\mathrm{C}-\mathrm{Cl})$ is partly compensated by a back donation of electron density from the antibonding $\sigma^{*}(\mathrm{CH})_{\text {trans }}$ orbitals to $\mathrm{LP}(\mathrm{N})$, i.e., a weakening (or hampering) of the negative hyperconjugation effect, as illustrated in Fig. 7.

The weakening of negative hyperconjugation is also confirmed by a decrease in the $\Sigma E^{2} \mathrm{LP}(\mathrm{N}) \rightarrow \sigma^{*}(\mathrm{CH})_{\text {trans }}$ values by $-0.57,-1.13$ and $-1.67 \mathrm{kcal} \mathrm{mol}^{-1}$ in methylamine, dimethylamine and trimethylamine complexes, respectively. Moreover, the corresponding $\mathrm{C}-\mathrm{H}$ bonds are contracted by -0.002 or $-0.003 \AA$, and the $\mathrm{C}-\mathrm{H}$ stretching frequencies are blueshifted by 23 or $26 \mathrm{~cm}^{-1}$.
Based on the presented results, it can be concluded that the formation of halogen-bonded complexes between methylated amines and $\mathrm{F}_{3} \mathrm{CCl}$ leads to an increase in the $\mathrm{CT}$ from $\mathrm{LP}(\mathrm{N})$ to $\sigma^{*}(\mathrm{C}-\mathrm{Cl})$ in the order methylamine $<$ dimethylamine $<$ trimethylamine. This causes an increase in the $|\Delta E|$ in the same order. Simultaneously, the weakening of the transfer of the electron density from the LP(N) to $\sigma^{*}(\mathrm{CH})_{\text {trans }}$ orbitals takes place. The largest weakening of the negative hyperconjugation has been found in the most stable (the largest $|\Delta E|$ ) trimethylamine complex (with the smallest value of the $\left.\left|V_{s, \min }\right|\right)$, while the smallest weakening of the negative hyperconjugation has been found in the less stable (the smallest $|\Delta E|$ ) methylamine complex (with the largest value of the $\left.\left|V_{s, \text { min }}\right|\right)$.
Fig. 7 Charge transfer between $\mathrm{LP}(\mathrm{N})$ and $\sigma^{*}(\mathrm{C}-\mathrm{Cl})$ orbitals and a simultaneous weakening of negative hyperconjugation between $\mathrm{LP}(\mathrm{N})$ and $\sigma^{*}(\mathrm{C}-\mathrm{H})_{\text {trans }}$ orbitals

\section{complex $\mathrm{F}_{3} \mathrm{CCl} \bullet \bullet \mathrm{NH}_{2} \mathrm{CH}_{3}$}

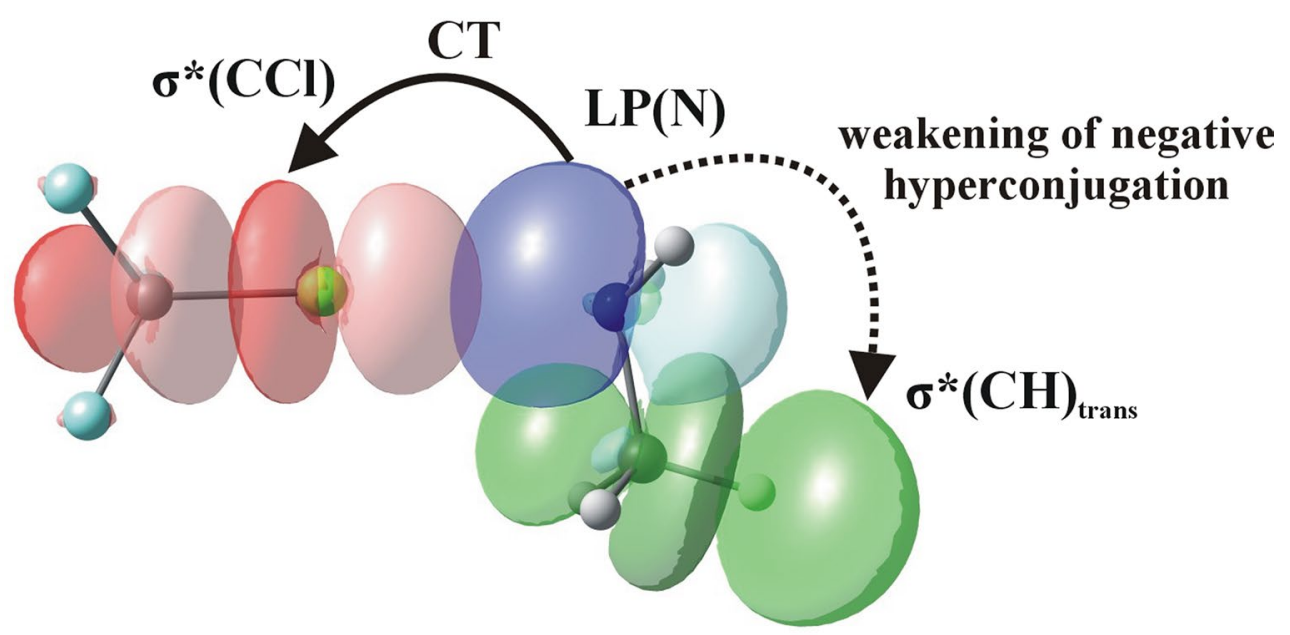


This indicates that the weakening of the negative hyperconjugation is probably responsible for the inverse correlation (negative correlation) between $\Delta E$ and $V_{s, \min }$ in the complexes of methylated amines.

\section{Conclusions}

1. For the investigated halogen-bonded complexes, the interaction energies $(\Delta E)$ calculated at the $\operatorname{CCSD}(\mathrm{T}) / \mathrm{cc}-\mathrm{pVTZ}$ level range between -0.90 and $-2.57 \mathrm{kcal} \mathrm{mol}^{-1}$. The calculated at the BLYPD3/Def2TZVPP level $\Delta E$ vary from -1.56 to $-4.81 \mathrm{kcal} \mathrm{mol}^{-1}$.

2. In the case of the chlorinated amine complexes, the linear correlation between $\Delta E$ and $V_{s, \min }$ was found with positive correlation coefficients $R^{2}$ of 0.952 . The inverse (negative) correlation was observed for the methylated amines $\left(V_{s, \min }\right.$ was decreasing with increasing $\Delta E$ ), with a correlation coefficient of 0.940 .

3. In all the complexes studied in this work, the AIM analysis reveals the presence of only one attractive interaction confirmed by a $\mathrm{BCP}$ between the $\mathrm{N}$ and $\mathrm{Cl}$ atoms.

4. In the isolated methylated amines, the decrease in the occupancy of the $\mathrm{LP}(\mathrm{N})$ is caused by the charge transfer from $\mathrm{LP}(\mathrm{N})$ to the antibonding $\sigma^{*}(\mathrm{CH})$ orbitals of the methyl group(s). This stabilizing intramolecular interaction is called negative hyperconjugation.

5. The NBO analysis has revealed that upon complexation of chlorinated and methylated amines with $\mathrm{F}_{3} \mathrm{CCl}$ the CT from the $\mathrm{LP}(\mathrm{N})$ to the $\sigma^{*}(\mathrm{CCl})$ orbital occurs. This $\mathrm{CT}$ stabilizes the complexes.

6. In the halogen-bonded complexes of $\mathrm{F}_{3} \mathrm{CCl}$ with methylated amines, the occupancy of the $\mathrm{LP}(\mathrm{N})$ orbital results from two effects: the $\mathrm{CT}$ from $\mathrm{LP}(\mathrm{N})$ to $\sigma^{*}(\mathrm{CCl})$ antibonding orbital and the weakening (or hampering) of the negative hyperconjugation $\mathrm{LP}(\mathrm{N}) \rightarrow \sigma^{*}(\mathrm{CH})_{\text {trans }}$. The former effect leads to a decrease in electron density (ED) on the LP(N) orbital, while the latter effect causes an increase in ED on the LP(N) orbital. The largest weakening of the negative hyperconjugation has been found in the most stable (the largest $|\Delta E|$ ) trimethylamine complex. It should be noted that the isolated trimethylamine has the smallest value of $\left|V_{s, \min }\right|$. On the contrary, the smallest weakening is noted in the less stable (the smallest $|\Delta E|$ ) methylamine complex (where $\mathrm{NH}_{2} \mathrm{CH}_{3}$ has the largest value of $\left.\left|V_{s, \min }\right|\right)$. These effects can explain the inverse (negative) correlation) between $\Delta E$ and $V_{s, \min }$.

Acknowledgements This work was financed in part by a statutory activity subsidy from the Polish Ministry of Science and Higher
Education for the Faculty of Chemistry of Wroclaw University of Science and Technology. A generous computer time from the Wroclaw Supercomputer and Networking Center is acknowledged.

Open Access This article is distributed under the terms of the Creative Commons Attribution 4.0 International License (http://creativecommons.org/licenses/by/4.0/), which permits unrestricted use, distribution, and reproduction in any medium, provided you give appropriate credit to the original author(s) and the source, provide a link to the Creative Commons license, and indicate if changes were made.

\section{References}

1. Metrangolo P, Resnati G (2008) In: Mingos DMP (ed) Halogen bonding; structure and bonding. Springer, Berlin

2. Metrangolo P, Carcenac Y, Lahtinen M, Pilati T, Rissanen K, Vij A, Resnati G (2009) Science 323:1461-1464

3. Präsang C, Whitwood AC, Bruce DW (2009) Cryst Growth Des 9:5319-5326

4. Pigge FC, Vangala VR, Kapadia PP, Swenson DC, Rath NP (2008) Chem Commun 39:4726-4728

5. Mele A, Metrangolo P, Neukirch H, Pilati T, Resnati G (2005) J Am Chem Soc 127:14972-14973

6. Parisini E, Metrangolo P, Pilati T, Resnati G, Terraneo G (2011) Chem Soc Rev 40:2267-2278

7. Wilcken R, Liu X, Zimmermann MO, Rutherford TJ, Fersht AR, Joerger AC, Boeckler FM (2012) J Am Chem Soc 134:6810-6818

8. Liu R, Loll PJ, Eckenhoff RG (2005) FASEB J 19:567-576

9. Metrangolo P, Pilati T, Terraneo G, Biella S, Resnati G (2009) Cryst Eng Commun 11:1187-1196

10. Zefirov NS, Makhon'kov DI (1982) Chem Rev 82:615-624

11. Boterashvili M, Lahav M, Shankar S, Facchetti A, van der Boom ME (2014) J Am Chem Soc 136:11926-11929

12. Abate A, Saliba M, Hollman DJ, Stranks SD, Wojciechowski K, Avolio R, Grancini G, Petrozza A, Snaith HJ (2014) Nano Lett 14:3247-3254

13. Karpfen A (2008) In: Metrangolo P, Resnati G (eds) Halogen bonding, fundamentals and applications. Springer, Berlin

14. Ivanov DM, Novikov AS, Ananyev IV, Kirina YV, Kukushkin VY (2016) Chem Commun 52:5565-5568

15. Desiraju G, Shing Lo P, Kloo L, Legon AC, Marquardt R, Metrangolo P, Politzer P, Resnati G, Rissanen K (2013) Pure Appl Chem 85:1711-1713

16. Murray JS, Lane P, Politzer P (2009) J Mol Model 15:723-729

17. Politzer P, Murray JS, Clark T (2010) Phys Chem Chem Phys 12:7748-7757

18. Murray JS, Riley KE, Politzer P, Clark T (2010) Aust J Chem 63:1598-1607

19. Politzer P, Murray JS, Concha MC (2007) J Mol Model 13:643-650

20. Cavallo G, Metrangolo P, Milani R, Pilati T, Priimagi A, Resnati G, Terraneo G (2016) Chem Rev 116:2478-2601

21. Adhikari U, Scheiner S (2012) Chem Phys Lett 532:31-35

22. Nepal B, Scheiner S (2015) Chem Phys 456:34-40

23. Scheiner S (2013) Int J Quantum Chem 113:1609-1620

24. Riley KE, Murray JS, Fanfrlik J, Rezac J, Sola RJ, Concha M, Ramos FM, Politzer P (2011) J Mol Model 17:3309-3318

25. Riley KE, Murray JS, Politzer P, Concha MC, Hobza P (2009) J Chem Theory Comput 5:155-163

26. Politzer P, Murray JS (2013) Chem Phys Chem 14:278-294

27. Politzer P, Lane P, Concha M, Ma Y, Murray JS (2007) J Mol Model 13:305-311 
28. Politzer P, Murray JS, Clark T (2013) Phys Chem Chem Phys 15:11178-11189

29. Zierkiewicz W, Bieńko D, Michalska D, Zeegers-Huyskens T (2015) J Comput Chem 36:821-832

30. Nziko VP, Scheiner S (2015) J Phys Chem A 119:5889-5897

31. Zierkiewicz W, Michalczyk M, Bieńko D, Michalska D, ZeegersHuyskens T (2017) Int J Quantum Chem 117:e25369

32. Grimme S, Antony J, Ehrlich S, Krieg H (2010) J Chem Phys 132:154104

33. Weigend F, Ahlrichs R (2005) Phys Chem Chem Phys 7:3297-3305

34. Weigend F (2006) Phys Chem Chem Phys 8:1057-1065

35. Sedlak R, Janowski T, Pitonak M, Rezac J, Pulay P, Hobza P (2013) J Chem Theory Comput 9:3364-3374

36. Boys SF, Bernardi F (1970) Mol Phys 19:553-566

37. AIMAll (Version 14.11.23), Todd AK, TK Gristmill Software, Overland Park KS, USA, 2014 (aim.tkgristmill.com)

38. Bulat FA, Toro-Labbe A, Brinck TE, Murray JS, Politzer P (2010) J Mol Model 16:1679-1691

39. Bulat FA, Toro-Labbe A, WFA: a suite of programs to analyse wavefunctions, unpublished

40. Reed AE, Curtiss LA, Weinhold F (1988) Chem Rev 88:899-926

41. Glendening ED, Badenhoop JK, Reed AE, Carpenter JE, Bohmann JA, Morales CM, Weinhold F (2001) NBO 5.0 Software (Theoretical Chemistry Institute, University of Wisconsin, Madison, WI). http://www.chem.wisc.edu/ nbo5

42. Frisch MJ, Trucks GW, Schlegel HB, Scuseria GE, MA Robb, Cheeseman JR, Scalmani G, Barone V, Mennucci B, Petersson
GA, Nakatsuji H, Caricato M, Li X, Hratchian HP, Izmaylov AF, Bloino J, Zheng G, Sonnenberg JL, Hada M, Ehara M, Toyota K, Fukuda R, Hasegawa J, Ishida M, Nakajima T, Honda Y, Kitao O, Nakai H, Vreven T, Montgomery Jr JA, Peralta JE, Ogliaro F, Bearpark M, Heyd JJ, Brothers E, Kudin KN, Staroverov VN, Kobayashi R, Normand J, Raghavachari K, Rendell A, Burant JC, Iyengar SS, Tomasi J, Cossi M, Rega N, Millam JM, Klene M, Knox JE, Cross JB, Bakken V, Adamo C, Jaramillo J, Gomperts R, Stratmann RE, Yazyev O, Austin AJ, Cammi R, Pomelli C, Ochterski JW, Martin RL, Morokuma K, Zakrzewski VG, Voth GA, Salvador P, Dannenberg JJ, Dapprich S, Daniels AD, Farkas O, Foresman JB, Ortiz JV, Cioslowski J, Fox DJ (2009) Gaussian 09, Gaussian, Inc., Wallingford CT

43. Koch U, Popelier PLA (1995) J Phys Chem 99:9747

44. Popelier PLA (1998) J Phys Chem A 102:1873

45. Alabugin I, Gilmore KM, Peterson PW (2011) Wiley Interdiscip Rev Comput Mol Sci 1:109-141

46. Allinger NL, Rogers DW (2010) In: Allinger NL, Rogers DW (eds) Molecular structure. Wiley, Chichester

47. Alabugin I (2016) Probing stereoelectronic effects with spectroscopic methods, in stereoelectronic effects: a bridge between structure and reactivity. Wiley, Chichester

48. Bohlmann F (1958) Chem Ber 91:2157-2167

49. Lias SG, Liebman JF, Levin RD (1984) J Phys Chem 13:695-808

50. Chandra AK, Parveen S, Das S, Zeegers-Huyskens T (2008) J Comput Chem 29:1490-1496 